\title{
清酒業界の二, 三の問題
}

\section{口渡辺八 郎*}

\section{1. 生 産 方 針}

技術汇関する問題だけを取り上げたいのであるが，生 産方針とか生産量等は総ての根本をなすものであるから このことについても多少はふれて見たいと思5。36 酒 造年度の生産方針については，增酸酒の製造割合につい て大きな問題を残したことは周知の通りである。また割 り当てられた原料米の 1 割を限度として自由生産を認め られたことも大きな変化である。本年度洁どうなるであ ろらか，こ机侣総ての生産者の関心事であって本年度の 大きな問題でるむる。こう言ら問題は政治的色彩が多分 に含まれているので技術者の深く立ち入るべき問題で代 ないようであるが，或る程度の增産と自由生産の方向に 向うことは技術者としても想像に難くないし，またアル

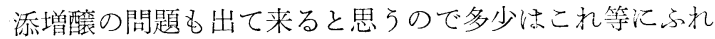
て見ることにした。昭和 17 酒造年度からアル添の才法 が始められ，昭和 24 酒造年度から增酸法が実施されて 夫々相当の月日がたっているので，その製造方法沉も馴 れて来ているし，また我及技術者（杜氏も含む）江清酒 の製造方法がいかに変化されても消費者汇愛好される酒 質の清酒製造に向って努力して来ている。そしてそれな りに実効もめったものと信じている。增酸酒を始めた頃 怯色々と增醇酒の酒質に対する批判もあったが今で注製 造方法にもすっかり馴れているし，普通酒とのブレンド によって一般の嗜好化合致する酒質の製造法も会得して いる。どんな田舎婂行っても一般消費者から清酒の品質 がよくなったと喜ばれている現状である。この馴れた方 法を急变させることは製造方法の急变を意味することに なる。10 年以上もかかって馴れて来た製造方法を急変 させればその結果について危ぐの念を抱くのも無理もな いことと思う。

一面から見ればそんな酒沉一般の搘好が馴れて来てい

* 日本酒造組合中央会
るのにこれを急変させることにもなる。優秀な技術者を 持っている生産者踏として大部分の生産者は生産方針 を変化させるにしても漸次変化させることを希望してい るのではないだろらか，従ってアルコールとか糖分等は 或る限度を定めて生産者の自由避択委か与法が考光出 されたのだらう。顧客によってはアルコール無添加酒を

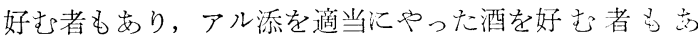
り，この好み汇従って最良と思わ机る品質の清酒学供給 するのが生産者の義務でもあり，これを造るのが技術者 の義務でもある。大量を販売して大鼻を自分の好及汇吸

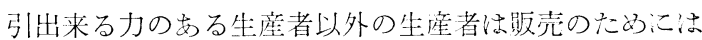
大体汇和いて自分の好及を捨てているのが現状である。 また，これ等アルコール，糖分等の源加出来ること法消 酒業者の一大特具と考考兄れるので，これを放童する ことに慎重でせって欲しいと思うものである。本年は

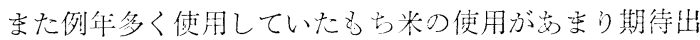
来ないとしたら，こ机代るべき出んなお法も考览しな ケればならない。

\section{2. 生産数量と中小生産者}

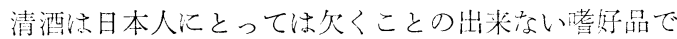

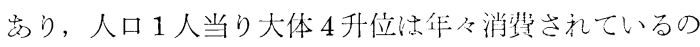
で为るから消費量も年增加し，従って今後の生産方剑 がぞう変ろらと年々增産されて行くものと思示机る。 だこの時四千業者全部が同じ歩調で伸びて行くかどうか

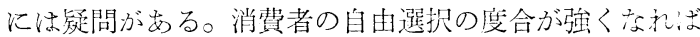
なる程伸びる鉻柄と伸びなや先銘柄とが出来て来るのて

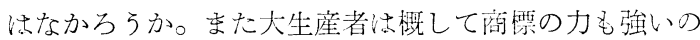
が普通であるから大生産者が增産によって生机た大量の 印むのが全国汇広がって行くときはどらしても地うの中

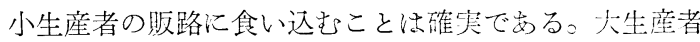
はごうも中小生産者を压迫する気持快ないとても自然 汇压迫する形となることは必至である。これて詨し中小 生産者はどらしたらよいか。これ法流んとうに切実な問 
題である。企業の合理化をして対抗すべきであると言わ れるが，この企業の合理化と言うことは，言うのは簡単 であるが現実としては仲々困難な問題である。四千業者 の心理状態や所在地に扔活る社会的地位等の関係で簡単 には踏み切れない問題である。ぞうにかなるだろうと安 易には考兄られない切実な問題ではあるが当分の間は現 在のままで進むのが止むを得ないことで岒ないだろう か。現在のまま進むとしたら中小生産者はどうしたらよ いか，仲々もずかしいことではあるが自分の従来の販路 を守ることが第一で次泳路の拡張である。このために はサービスもよくせねばならねし， P. R もせねばなら 队, 然しこれ等については大生産者にはとうていついて 行汁ないことであって，販売数量から見てもその余裕が 生れて来ない。それで中小生産者は自己の販路を守るた めには顧客を離さないだけの品質を維持して行くこと と, 自己の社会的地位に相当したサービスをその所在地

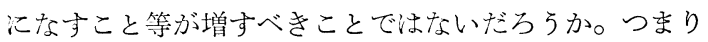
その所在地の地方大事に進むことである。飲み馴れた酒 の味と言うものはありがたいもので仲々離れ難いもので あるから，この顧客を十分引きつけて置くだけの品質の ものは如何なることをしても供給せ㸚ばならない。精米 歩留を $5 \%$ だけ他の生産者より少なくするとすれば清酒 の品質识相当上昇させること法可能である。この $5 \%$ の 原料米の代金は大体汇扮いて市肘酒 1 升当り 2 円程度の ものであるから，これが最も効果的なサービスではなか らうか。だから中小生産者怡大生産者の出来ないかゆい 所汇手が届くように丁寧に優良酒を造って, これを供給 して販路を確保することが第一にやるべきことと思う。 新しい便利な工場と機戍類を十分設備寸ることは望まし いことであり，労務者を確保するに惊必要なことではあ るが優良酒を造るには必らずしも絶対的化必要なもので 沈ない，現在持っている設備で原料と技術とを吟味すれ 壮出来ないことはないと思う。ただ中小生産者は清酒の 貯蔵管理と出荷技術との研究が不足していることはない だろうか, 市販清酒の優劣が販路の確保汇最も重大であ

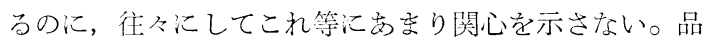
評会用清酒の出品技術が現在程発達しているのに出荷技 術が出来ない管䛱ないと思う。

\section{3. 新しい酒}

本年四月から酒税法が改正されて清酒もアルコール変

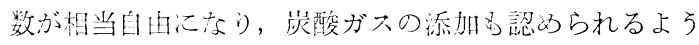
になったので, アルコール度数の色々な清酒やガス入り 清酒が生れるようになった。高濃度清酒とガス入り清酒 とが新製品となるわ活であるが，高濃度清酒はどの生産 者も直ち出荷出来るものであるががス入り清酒怯そう
は行かない。ガス入り清酒も商品である以上ガスの量, 糖分, 酸等の成分量が略々一定したものを出荷しなけれ ばならない。従ってガス量を自然酘醳法によって含ませ るものとすれば恐らく一定したガス圧力とはならないだ ろらから, ガス入り清酒は酒税法で許される範囲内で清 酒汇必要量の成分量を含ませて，これを冷却し炭酸ガス を含ませた後に一定量をびん詰めして製品とすることと なると思らが, この時のアルコールの量, ガスの圧力, 糖分, 酸分, 香気等がぞの程度が最も効果的であるかは 研究を要する問題である。清酒の香気と言うものは微妙 なもので一寸したことで色々と変化するものであるから ガス入り清酒には一定の香料が入れられて一定の香気と することが出来たらな技一層有効であったと思うのだが 税法上添加を認められないことになったの残念であ る。ガス入り清酒の一定した製品を出荷することは仲々 困難なことであるから誰でる簡単に出荷出来ると言うわ けには行かない。清涼飲料製造の経験等も或る程度要す るものである。こんな関係で消費も急にそう期待出来な いだろうし，また長い間の研究と努力とを必要とする製 品である。何しろ清酒は長い閒の伝統によって訓練され て落らついて来た飲料であるから新製品が出たからと言 って急にその消費量が期待出来るとは考光られない。い く分なりと消費が増大する程度のものではなからうか。 清酒は日本人にとっては世界中で一番旨い酒ではせるが 非常汇繊細な酒であるから一寸でも他の酒が入ると清酒 のよい持ち味が消されてしまう。だからカクテルのベー スとしてはもったいないような気がする。清酒法アルコ ール分 14〜16 度のものなら燜でよし，冷でよし，オン ザロックでも亦よしと言う所洛落ちついて来たものであ るからこれ等を本隊としてもっと婦人層汇も外国から来 る人々にも P. R すべきであると思う。ガス入り清酒と かソフトや高濃度酒はとの補助的のもので㤁って消費量 も補助的ものではなかららか。然し幸いなことに色々 と種類の変ったものが出荷出来るようになったのである から，あらゆる機会をとら兄て販路を拡張すべきである 5。

\section{4. 労 務 関 係}

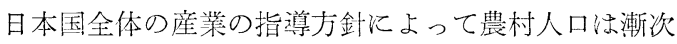
減少の一途をたどって来ているのでその影響を受けて酒 造労務者も減少を来し, 毎年若い労務者の雇、入れ注は 相当の困難壱感じている。製造も四季釀造として常時雇 用の労務者比切り替えな汀ればならないと言われている が，将来は知らず当分の間は現状の季節労務者に頼らな ければならないと思う。従って現在の状態に扣いて労務 関係をどうすれば生産者も労務者も或る程度満足し得ら 
れるかを研究しなければならない。現在労務者が酒造労 務で最もいやがっているのは労務それ自体でなく労務時 間の問題である。酒造労務は農村労務に比較して決して 重労㗢とは思わない。ただ近代産業に比較して労務時間 が一定していない。自由時間が不足している等のことが 不平の原因だと思う。これ等の問題岕考光一つで解決出 来ることで現在でも相当数の生産者が八時間労働制にふ 又切って生産している。夜間労務を無くしている工場な どは相当数にのぼっているのではないだろらか。ただこ のときに問題なのは労務者が自分の自由時間を相当持つ ことになれば労賃の消費が多くなって, 郷里以持ち帰る 金額が少なくなるお先それがあることである。郷里の親達 や直接労務者を引卒して来る杜氏にとってはこのことは 最も注意していることであるから自由時間の多くなるこ とを極度に嫌う傾向にある。自由時間は多くして欲し い，帰郷する時の給料証多く欲しい之言５のでは仲々解 決は困難である。学務問題の解決に汹楖里の親達とか杜
氏の協力なくては解決出来ないことであるが，まずこれ 等の人達も近代産業らしい考光方になって生産者共々解 決をはかるべきではなかららか。今迄の清酒造りは手が 込文ずて必要以上に気を使っている点も多々あるよう に思われるのであるから，技術の進歩した現在で法整理 すべきは整理して労務時間の解決をはかるべきである。 自由時間中の僓銀の消費等については個人の意志を尊重 してその自覚に穼か世外部からかれこれ束縛する必要が ないように思らがぞらだろらか。

また，今後労賃は次第に上界の線をたどることである らから出来るだけ仕事は機械力をかり，人力によること はさける方向に研究すべきである。

終りに近来失業保険法が普及するにつれて時折り問題 を起すかのように伝觉られるが，これは労務者全体のた めに十分公共職業安定所と連絡を密にして自重されんこ とを願うものである。

\section{一 口辞 典}

セルラーゼ(瀻維素分解酵素)： 近年酵素を取り扱ら枝術が進歩し， 食品の加工方面にも応用出来るよ うになった。最近酵素製品として 使用し始めたたルラーゼは, 緎維 を加水分解しセロビオーズ（葡萄 糖が 2 ケ結合したもの）又はセル ロデキストリンと葡萄糖を作る。 この醅素は1906 年にカタッムリ の肝・スイ臓液から見出されてい たが，最近かびや細菌などにも存 在している事が分った。この酵素 は酸や熱に対して非常に安定であ り, 又最適 $\mathrm{pH} 3.5$ 付近で, 作用 範因は 2.5〜8.0 と非常に広い。 䤁造関係で使用すれば，もろみを 分解して更に醱酵性の糖を作るの で，収量がすすといわれている。

突然変異 : 突然変異の中には自 然的なものと人為的なものとに区
別される。前者は意識的に突然変異 を誘発させるような種々の刺激を与 えなくとも自然に起るもので, 微生 物の場合種によっても異るが $10^{-8}$ 〜 10-10 の割合で自然的な变異がお こっている。即ち $10^{8}$ (1 億) の細 菌集団があって，それが 1 回分裂を 行ったと仮定すると，この細菌の内 の 1 ケが突然变画を抗こす事を意味 する。人為的突然变異は, 放射線や 化学薬品を用いて行い, 出来た突然 变異株を用いて染色体の異状の発生 機構や遺伝子の化学的作用などを調 ベる遺伝学上の問題解明と, 品種改 良を行ら実際上の利用に応用されて いる。

$\mathrm{ppm} \cdot \mathrm{ppb}$ : ごく微量の化学成 分を測定する場合に用いられる単位 であって, ppm (parts per millon) 即ち 100 万分の 1 の単位と, ppm の 更に 1/1000 の単位を表わすのに ppm（parts per billion）がある。 $\mathrm{ppb}$ は 10 億重量単位溶媒中の溶質 の重量単位数をいい, 溶質の比重が 1 である場合は, 溶媒 $1 \mathrm{~m}^{3}$ 中の溶
質の $\mathrm{mg}$ 数を表わす。 ppm は同じ く比重 1 の場合, 溶媒 $10 \mathrm{~cm}^{3}$ 中 の $\mathrm{mg}$ 数を表わす。 $\mathrm{ppb}$ 単位は, 水質関係の用語として最も多く用 いられ, 科学枝術の進歩に伴い, 用水の水質の問題もしだいに精密 度を高め, また水処理技術, 水質 分析技術なども並行的に高度化し た結果, $\mathrm{ppb}$ 単位の不純物が大き な意味を持って来た。

\section{バイオアツセイ (生物学的定量)} : 生物の生存維持や発育々の他何 らかの機能にとって不可欠な, あ るいは阻害的な物質の量を, 生物 の生活現象の計測によって定める 方法である。微生物を試験生物と した測定方法は可成り多く利用さ れており，ビタミン類やアミノ酸 などの定量は, 化学的な分析方法 によるよりも本法を用い生物学的 効果を標識とした方が便利の專が 岕る。 